International Journal of Zakat Vol. 4(2) 2019 page 101-110

\title{
A Maqasid and Shariah Enterprises Theory-Based Performance \\ Measurement for Zakat Institution
}

\author{
Ataina Hudayati and Achmad Tohirin \\ Universitas Islam Indonesia
}

\begin{abstract}
This study aims to develop a performance measurement system for zakat institutions from the perspective of maqashid al-Shariah and Islamic enterprise theory. This study embarks from previous studies focusing on the performance measurement methods applied to the zakat institutions. The understanding of maqashid al-Shariah in this paper refers to the concept formulated by Al Ghazali and Ibn Ashur. The basis of selecting so is their widely known concept in the contemporary research. This paper concludes that the performance measurement based on maqashid al-Shariah for Islamic bank can be adopted in zakat institution by making various adjustments according to the characteristics of the institution. In addition, this study also designed a performance scorecard to assess the performance of zakat institutions based on maqashid al-Sharia and Islamic enterprises theory. This scorecard method can calculate the index of zakat management of the related institution from a broader perspective.
\end{abstract}

Keywords: performance, measurement, maqashid al-Shariah, enterprise theory

\section{INTRODUCTION}

Poverty is a classic problem that massively occurs in developing country. Poverty is a complex problem. Poverty and its implications can involve all aspects of human life. To reduce the problem of poverty, Islam offers zakat as a comprehensive solution. That is, one of the reasons for establishing zakat institution is to improve the effectiveness of zakat management. In Indonesia, such government institution is called as the National Boar of Zakat, Republic of Indonesia (BAZNAS), while those the private ones called Lembaga Amil Zakat (LAZ). Both are governed under the low No. 23 of 2011.

According to National Zakat Statistics 2017 published by BAZNAS, the number of zakat institution in Indonesia reaches to 603 institutions. However, the overall percentage of zakat collection in the nationwide of Indonesia for 2017 period, only reached 2.9 percent from its potential of Rp. 217 trillion (BAZNAS, 2018). Aibak (2015) argued that one of the reasons for the low concern of the community in paying zakat formally to the institution is because the institution's method of collection. In some cases, the zakat management institution seems to be passive in collecting zakat.

In order zakat can achieve its objectives, the institution must be in accordance with the objectives of Shariah or maqashid al-Shariah. Maqashid al-Shariah is the basic paradigm of Islamic economics (Muzlifah, 2013). The importance of maqashid al-Shariah concept has been addressed by some researchers. In the context of zakat institution, Hapsari and Abidin (2016) examined the distribution of zakat based on the maqashid alShariah framework. The same attempt was also done Mardiah and Jamil (2016) 
who reviewed the effectiveness of the distribution of zakat at the Dompet Dhuafa (DD) Palembang. The results of the study show that through various programs, DD Palembang has been able to promote maqashid al-Shariah in the local context.

Furthermore, Fitria (2018) examined the conformity of social entrepreneurship programs in zakat institutions using maqashid al-Shariah and sampled DD for a case study. The work highlighted the significance of the concept to be employed when analysing the performance of Zakat institution. In like manner, Nugroho \& Wahyuni (2019) elaborated upon the necessity of maqashid al-Shariah to develop a framework for designing and implementing performance measurement. They tested their method by measuring the performance of the alHaromain zakat institution in Malang based on the concept of the balanced scorecard and the perspective of maqashid al-Shariah. These reviewed studies indicated the importance of considering maqashid al-Shariah when analysing the performance of Zakat institution.

As elaborated in the above text, this study aims to expand the previous studies by constructing more comprehensive model of performance measurement for zakat institution based on maqashid al-Shariah and Islamic enterprise theory. This study integrates these concepts for a comprehensive method of measurement.

Measuring the performance of zakat institutions is important. This is because in general, the need to assess the effectiveness and the efficiency of zakat institutions is vital for their improvement. The simplest way to evaluate the effectiveness of zakat institutions is by looking at the speed of transformation of converting a mustahik to be a muzakki, even to achieve so requires an extensive work. Thus, it is interesting to assess the degree to which a zakat institution has been endorsing the concept of maqashid al-Shariah, particularly in the context of Indonesia.

In the next section, the theoretical explanation is discussed further covering the concept of maqashid al-Shariah, the innovation in the management of zakat and the understanding of stakeholder theory. Further, the discussion also mainly reviewed some relevant previous studies. The main part of this paper establishes the design of performance measurement for zakat management. Finally, this paper provides conclusions, implications and suggestions.

\section{LITERATURE REVIEW}

\section{Maqashid al-Shariah}

According to al-Syathibi as quoted by Aibak (2015), the Shariah actually aims to realize the welfare of humans in the world and the hereafter. From this basis, it is clear that in fact the laws were not made for the law itself but were made for the purpose of all human being. Muhammad Abu Zahrah asserted that the welfare for all human being should be achieved through individual education, the realization of justice and welfare of the community (Mohammed et al. 2008).

Al-Ghazali as mentioned in the study of Syofyan (2017), stated that the primary purpose of Shariah is to promote human welfare, which lies in protecting the followings;
a. faith (din),
b. life (nafs),
c. intellectual (aql),
d. progeny (nasl), and
e. wealth (maal). 
Further, Mulyana (2017) concluded the concept of welfare in Islam, which is rooted from $\mathrm{Al}$ Ghazali's notion of maqashid al-Shariah. In the study, maqashid al-Shariah is believed to be the most comprehensive concept of welfare. That is because the concept not only covers the elements of material needs but also moral and spiritual aspects. Thus, it what differs from the concept of welfare which is promoted by the western concept, which only focuses on the material aspects.

Based on the above explanation, it is clear that maqashid al-Shariah has not only the dimension of the worldly aspect but also the hereafter.

\section{Innovation in zakat management}

Komariyah (2013) explained the main purpose of zakat is to realize justice. Therefore, zakat is required in narrowing economic inequality in the society, by distributing it specifically to certain groups who we call them as Mustahiks (zakat recipients). As prescribed in alQur'an, zakat is distributed to eight ashnafs, which are;

a. Fakir (the poor),

b. Amil (now can be described as those who work in Zakat institution),

c. Muallaf (those who revert to Islam)

d. Slaves,

e. People who are in debt,

f. Fisabilillah and

g. The wayfarer.

There are many innovations in management of zakat to increase the benefit of zakat to the society. One of them is the concept of productive zakat. According to Aibak (2015), zakat distribution can be classified into four;

a. Zakat distributed traditionally for consumption,

b. reative consumptive, c. traditional productive and

d. creative productive.

Traditional consumptive is the distribution of zakat to be used directly by the mustahik, to meet their daily needs. The creative consumptive is the distribution of zakat which is manifested in other forms of the original goods, but still in the consumptive category, for example zakat is distributed in the form of school tools or scholarships.

Furthermore, traditional productive zakat is the distribution of zakat given in the form of productive goods such as buying goats, cows, commercial equipment and so on. Finally, creative productive zakat, which is the distribution of zakat which is made in the form of business capital.

According to Muhammad \& Mas'ud (2005) as quoted in Ningrum (2016), productive zakat is the giving of zakat enabling the recipients to sustain the property from the received zakat. In other word, productive zakat is zakat where the assets or zakat funds given to Mustahik are not directly spent but it converts into a capital like asset. This is done to strengthen their businesses capacity and capability. By musthaik being enhanced their capacity and capability, their business will be able to generate more income and profit. Finally, they can fulfil their needs sustainably.

There are four models of productive zakat distribution (Muhammad, \& Mas'ud, 2005). First, budget surplus model. In this model, zakat is partly distributed and the rest is used for productive projects. Second, in kind model. It is a system of zakat distribution where zakat funds are not distributed in the form of money but are given in the form of production equipment. Third, the revolving fund model. This model provides loans to the mustahik in the form of qardhul hasan 
financing. The mustahik is to return the initial amount of loan.

\section{Shariah enterprises theory}

This theory was developed by Triyuwono (2001). The idea that profitoriented or stockholders-oriented in conventional companies are seen to be not the right orientation for Islamic companies. To replace the concept of stockholders-oriented, the author suggested the use of Shariah enterprises theory which is oriented to zakat (zakatoriented), oriented to preservation of nature (natural environment) and oriented to stakeholders.

Furthermore Triyuwono (2001) explained that the orientation of zakat means that the company will strive to achieve the optimum realization of zakat (both material and value). Then the environment and stakeholder-oriented has the implication that Shariah organizations must have a concern to distribute the "welfare" (added value) that has been successfully created to nature and stakeholders. This Shariah enterprises theory has been used by Hermawan \& Rini (2016) to analyze the effectiveness of the management of zakat institutions. In their research, Hermawan \& Rini (2016) claimed that the sampled zakat institution had performed its obligations to God, and to stakeholders. However, for obligations to nature and employees have not been fully met.

\section{Maqashid-Based Performance Measurement Model for Islamic Banks}

Mohammed, et al. (2008) developed performance measurements based on Abu Zahrah's maqashid al-Shariah. These include;

a. individual education,

b. establishing justice, and

c. public interest.
Based on the Abu Zahrah concept, Mohammed et al. (2008) designed a technical performance measures for Islamic banks. The work done by Mohammed et al. (2008) has significantly influenced scholarly discussion on measuring the performance of Islamic banks. For example; the recent study done by Hudaefi \& Noordin (2019); Kholid and Bachtiar (2015), and among others, are the example of how the work of Mohammed et al. (2008) has credited the novelty to the general discourse of Islamic economics.

Furthermore, Mohammed et al. (2015) developed further the performance measurement for Islamic banks with employing the five elements of al-Ghazali's maqashid al-Shariah. These including preserving;
a. Religion,
b. Life,
c. Intellect,
d. Progeny, and
e. Wealth.

In designing performance ratios, Mohammed et al. (2015) employed the concept of maqashid of Al Ghazali with the concept of maqashid of Ibn Ashur as explained in Table 1.

Thus, from the above elaboration, it is rationale to develop the performance measurement based on maqashid al-Shariah in the context of zakat institution.

\section{Maqashid al-Sharia on Management of Zakat}

Mardiah and Jamil (2016) examined the suitability of zakat distribution program of DD Palembang with the concept of alGhazali's maqashid al-Shariah.

The results of the studycan be seen in Table 2. The researchers concluded that with the programs implemented, DD Palembang has been 
able to promote the five objectives of Shariah.

\section{MAQASHID AL-SHARIAH-BASED METHOD OF MEASUREMENTS FOR ZAKAT INSTITUTIONS}

\section{Benefit of Zakat for Mustahik}

The first stakeholder of zakat institution is mustahik. Mustahik will receive great benefits from zakat institutions depending on the quality of zakat distribution system.

Rahmawati (2011) argued that in the view of Islamic economics, the distribution system is part of economic activity that has a strong influence on the distribution of people's welfare. Distribution system according to Islam is a rule that cannot be separated from the provisions of maqashid al-Shariah. Therefore, there are two things that must be considered in an effort to improve welfare, they are;

a. Reducing the gap between community groups by opening jobs, and

b. Providing direct assistance to the poor, so that they can improve their quality of life.

According to Shariah, mustahiks who are staying around zakat institutions must get first priority to receive zakat. Once all the designated mustahik receive zakat, then the remaining zakat can be allocated to other regions. In addition, zakat managers also need to consider the form of zakat distribution whether zakat will be distributed in the form of traditional consumptive, creative consumptive, traditional productive or creative productive.

Amymie (2017) explained the programs carried out by BAZNAS can be classified based on sectoral grouping, namely; a. Economy;

b. Social and humanity;

c. Health;

d. Education; and

e. Preaching.

The distribution of zakat in BAZNAS must be considered in accordance with the maqashid alShariah.

\section{Benefit of zakat for Muzaki}

For muzaki, zakat is the implementation of one of the pillars of Islam. Therefore, by carrying out the obligation of zakat, muzaki has performed the first goal of maqashid al-Shariah, which is to preserve religion. In addition, zakat serves to purify property. Therefore, by paying zakat, muzaki has achieved the fifth element of maqashid al-Shariah, which is to preserve property. On this point, it can be understood that zakat institution has assisted muzaki in achieving two objectives of Shariah, which are preserving religion and preserving wealth.

Zakat institution must help muzaki to pay zakat correctly and properly. Therefore, the zakat needs to be socialized with Shariah rules to determine the amount of assets that are zakat-able. Knowledge and understanding of the assets owned such as income, living expenses, debts owned, primary and non-primary needs must be known and considered. In addition, socializing zakat to muzaki, the benefits received by muzaki may enhance the muzaki easiness for paying their zakat.

Aibak, (2016) in a study conducted at BAZNAS Tulungagung, provided an explanation on how zakat institutions can improve services to muzaki so that muzaki will be easier, comfortable and willing, to pay zakat. Zakat paid by employee in Tulungagung regency is collected by the zakat unit 
which is usually called as Unit Penerima Zakat (UPT). Following this, UPT proceeds the collected zakat to BAZNAS.

\section{Benefit for Amil}

Amil has the responsibility to manage zakat. With this responsibility, amil has sacrificed his time and energy to manage zakat institutions. Through their expertise, which requires formal and informal education, amil has worked for a significant contribution to the success of the zakat institution. Because of the contributions they have made, amil has the right to receive rewards for what they give.

In addition, most amil zakat working in zakat institutions are employees of zakat institutions. Perhaps the income from the zakat management organization is the only salary they receive. Therefore, the welfare of amil needs further attention, so that amil will get benefits, especially to get the fifth element of Maqashid al-Shariah; increase prosperity through wealth improvement.

Nevertheless, improving prosperity is not the only amil objective. Amil also has the right to get other maqashid al-Shariah elements that are preserved for their religion, life, intellect and descent. To preserve religion, zakat institutions may design programs such as religious lectures, congregational prayers and various other activities. To protect amils' children, the scholarship program is an appropriate alternative. Provision of amil salaries needs to be considered carefully, because Shariah rules limit amil rights to a maximum of $1 / 8$ of the amount of zakat received. Accordingly, amil welfare improvement can be attained by taking funds from other sources, for example unrestricted infaq or funding assistance from the state budget or regional budget. If salary payment system of zakat institution complies with Shariah rules, it will be possible for amil to obtain the five maqashid al-Shariah as explained before.

The benefits received by amil from zakat institutions are greatly influenced by the level of public trust on the zakat institutions. One important aspect affecting the level of public trust on zakat institutions is the accountability of zakat institutions. This is part of the findings of study done by Ikhwanda \& Hudayati (2019).

The findings of the study imply that zakat institutions need to improve their accountability to gain trust from the public. By enhancing trust from the public, zakat institutions will be able to develop and continue functioning effectively as a trusted institution. In addition to accountability, public trust is also influenced by the degree of transparency, professionalism and competency of zakat institutions in managing zakat.

\section{Benefit for naturelenvironment}

Shariah enterprises theory of Triyuwono (2001) stated that organizations based on Islamic principles must provide benefits to all stakeholders, both direct and indirect stakeholders, and provide benefits to nature. Nevertheless, the results of a study conducted by Hermawan \& Rini (2016) stated that zakat institutions have not fully been able to provide benefits to nature even though responsibilities to other stakeholders have been fulfilled.

\section{Performance measurement system for zakat institution}

Developing a quantitative performance measurement system is critical, so that an index can be produced to measure the performance of zakat institutions. This study suggests zakat institution to adopt 
the performance measurement scorecard. This method is designed following Mohammed et al. (2008) with some adjustments and contextualisation to the nature of zakat institution.

The authors of this paper are of the view that the performance measurements proposed by Mohammed et al. (2008) are more appropriate for measuring performance at the overall organizational level. This is due to the data used to measure performance ratios are taken from the annual reports and financial statements of zakat institutions as a whole. It is important to be noted that the weakness of the performance measurement is not considering whether the zakat institution has fulfilled its obligations to all stakeholders.

To make practical contributions to zakat institutions, this study designed a more comprehensive performance measurement scorecard that can be applied at the organizational level as well as the organizational unit level described in Table 3.

Table 1. Al-Ghazali and Ibn Ashur Maqashid al-Shariah

\begin{tabular}{ll}
\hline \multicolumn{1}{c}{ Maqashid Sharia Al Ghazali } & \multicolumn{1}{c}{ Maqashid Sharia Ibn Ashur } \\
\hline Preservation of religion/faith & Freedom of faith. \\
\hline Preservation of life/soul & $\begin{array}{l}\text { Preservation of human dignity. } \\
\text { Protection of human right. }\end{array}$ \\
\hline Preservation of intellect/mind & $\begin{array}{l}\text { Propagation of scientific thinking. } \\
\text { Avoidance of brain drain. }\end{array}$ \\
\hline Preservation of progeny & Care of family. \\
\hline Preservation of wealth & Wellbeing of society. \\
& Minimising income and wealth disparity. \\
\hline
\end{tabular}

Source: Adapted from Mohammed et al. (2015)

Table 2. Maqashid Sharia and Type of Program in Dompet Dhuafa

\begin{tabular}{ll}
\hline \multicolumn{1}{c}{ Maqashid Sharia Al Ghazali } & Program/Activities \\
\hline Preservation of religion/faith & Amazing Muslimah. \\
& Ramadhan. \\
\hline Preservation of life/soul & Health Services \\
& Mustahik Empowerment \\
& Home based clinic \\
\hline Preservation of intellect/mind & Educational Scholarship \\
\hline Preservation of progeny & Indonesia Creative Orphans \\
\hline Preservation of wealth & Farmer Empowerment \\
& Livestock's Empowerment and Beneficiaries \\
& Incubator \\
\hline
\end{tabular}

Source: Mardiah \& Jamil (2016). 
Table 3. Performance Measurement Scorecard for Zakat Institution

\begin{tabular}{|c|c|c|c|c|c|c|c|c|c|c|c|c|c|}
\hline \multirow{2}{*}{\multicolumn{2}{|c|}{$\begin{array}{l}\text { Program } \\
\text { Activitiy }\end{array}$}} & \multicolumn{5}{|c|}{ Maqashid al-Shariah } & \multirow{2}{*}{$\begin{array}{c}\text { Index/ } \\
\text { Item }\end{array}$} & \multicolumn{5}{|c|}{ Financial Benefit } & \multirow{2}{*}{\begin{tabular}{|c|} 
Index/ \\
Item
\end{tabular}} \\
\hline & & MS1 & MS2 & MS3 & MS4 & MS5 & & Muzaki & Mustahik & Amil & Nature & Society & \\
\hline 1 & A & 1 & 1 & 0 & 1 & 1 & 0.8 & 1 & 0 & 1 & 0 & 0 & 0.4 \\
\hline 2 & B & 0 & 1 & 1 & 1 & 1 & 0.8 & 0 & 1 & 0 & 0 & 1 & 0.4 \\
\hline 3 & $\mathrm{C}$ & 1 & 1 & 0 & 0 & 1 & 0.6 & 1 & 1 & 1 & 1 & 1 & 1 \\
\hline 4 & $\mathrm{D}$ & 0 & 0 & 1 & 1 & 1 & 0.6 & 1 & 0 & 1 & 0 & 0 & 0.4 \\
\hline 5 & $\mathrm{E}$ & 1 & 1 & 0 & 1 & 1 & 0.8 & 1 & 0 & 0 & 0 & 0 & 0.2 \\
\hline \multicolumn{2}{|c|}{ Index/Item } & 0.60 & 0.80 & 0.40 & 0.80 & 1.00 & & & & & & & \\
\hline \multicolumn{7}{|c|}{ Maqashid Index } & 0.72 & & & & & & \\
\hline \multicolumn{13}{|c|}{ Benefit Index } & 0.48 \\
\hline \multicolumn{7}{|c|}{ Performance Index } & 0.6 & & & & & & \\
\hline
\end{tabular}

Source: computed by Authors.

\section{CONCLUSION}

This study has discussed previous research related to performance measurement based on maqashid alShariah in general context of Islamic banking and linking it to the context of zakat institutions. The results of the existing scholarly works were found that significant efforts have been made to develop the concept of performance measurement, including for zakat institutions. To complement what has been designed by previous research, this study designed a performance measurement scorecard which function is to complement the existing performance measurements. The discussion in this paper leads to conclude that, the performance measurement techniques in zakat institutions consist of at least:

1) Performance measurements that identify the allocation of resources for each element of the maqashid al-Sharia;

2) Performance measurement that identifies the allocation of resources to each stakeholder;
3) Performance measures that integrate the concepts of maqashid al-Shariah, and Shariah enterprises theory (SET) as exhibited in Table 3, that identifies the programs carried out by zakat institutions to meet maqashid al-Shariah and fulfilled their obligations to all interested parties and stakeholders.

The performance measurement based on maqasid al-Shariah as developed in this study is relevant to zakat stakeholders. Zakat institutions may employ the developed benchmark to communicate their performance on maqasid al-Shariah, so that their efforts in actualising so is measurable.

\section{REFERENCES}

Aibak, K. (2015). Zakat dalam perspektif maqashid al-syariah. Ahkam: Jurnal Hukum Islam, 3(2), 199218.

Aibak, K. (2016). Pengelolaan zakat dalam perspektif maqashid al- 
syariah: Studi kasus di badan amil zakat Kabupaten Tulungagung. Ahkam: Jurnal Hukum Islam 4(2), 247-288.

Amymie, F. (2017). Optimalisasi pendistribusian dan pendayagunaan dana zakat dalam pelaksanaan tujuan program pembangunan berkelanjutan (SDGs). Anida:Aktualisasi Nuansa Ilmu Dakwah, 17(1), 1-18.

Fitria, A. (2018). Social entrepreneurship dalam perspektif maqashid al-syariah. Iqtisad, 4(1).

Hapsari, M. I., \& Abidin, Z. (2016). Zakat distribution in maqasid alshariah framework. Journal of Islamic Financial Studies, 2(02).

Hudaefi, F. \& Noordin, K. (2019). Harmonizing and constructing an integrated maqāṣid alSharī'ah index for measuring the performance of Islamic banks, ISRA International Journal of Islamic Finance, Vol. 11 (2), 282-302.

https://doi.org/10.1108/IJIF-012018-0003

Hermawan, S., \& Rini, R. W. (2016). Pengelolaan dana zakat, infaq, dan shadaqah perspektif Shariah Enterprise Theory. Riset Akuntansi dan Keuangan Indonesia, 1(1), 1224.

Ikhwanda, M.F., \& Hudayati, A. (2019). The influence of accountability, transparency, and affective and cognitive trusts on interest in paying zakat. Jurnal Akuntansi dan Auditing Indonesia 23(1), 3951.

Kholid, M. N., \& Bachtiar, A. (2015). Good corporate governance dan kinerja maqasid syariah bank syariah di Indonesia. Jurnal Akuntansi dan Auditing Indonesia, 19(2), 126-136.

Komariyah, O. (2013). Analisis implementasi maqashid syariah pada lembaga pengelola zakat dalam membangun konsep pemberdayaan masyarakat. ISLAMINOMICS, 4(1 ).

Mardiah, S., \& Jamil, M. A. (2016). Efisiensi alokasi berdasarkan maqoshid syariah: Studi kasus terhadap pola distribusi LAZ. IFinance: a Research Journal on Islamic Finance, 2(2), 21-33.

Mohammed, M. O., Razak, D.A. \& Taib., F.M. (2008). The performance of islamic banking based on the maqasid syariah. IIUM International Accounting Conference (INTAC IV). Putra Jaya Marriott, 25 June 2008.

Mohammed, M. O., Tarique, K. M., \& Islam, R. (2015). Measuring the performance of islamic banks using maqasid-based model. Intellectual Discourse, 23, Special Issue, 401-424.

Muhammad, \& Mas'ud, R. (2005). Zakat dan Kemiskinan: Instrumen Pemberdayaan Ekonomi Umat. Yogyakarta: UII Press.

Mulyana, R. A. (2017). Peran negara untuk mewujudkan kesejahteraan dalam kerangka maqashidus syariah. Al-Urban: Jurnal Ekonomi Syariah dan Filantropi Islam, 1(2), 155-175.

Muzlifah, E. (2013). Maqashid syariah sebagai paradigma dasar ekonomi Islam. Economic: Journal of Economic and Islamic Law, 4(2), 73-93.

Ningrum, R. T. P. (2016). Penerapan manajemen zakat dengan sistem revolving fund models sebagai upaya efektifitas penyaluran zakat produktif: Studi pada lembaga manajemen infaq Madiun. ElWasathiya: Jurnal Studi Agama, 4(1), 1-21. 
Nugroho, A., \& Wahyuni, N. (2019). Pengukuran kinerja dengan menggunakan balance scorecard dan pemahaman maqashid syariah. El Muhasaba: Jurnal Akuntansi, 10(1), 90-104.

Rahmawati, Y. (2011). Refleksi sistem distribusi syariah pada lembaga zakat dan wakaf dalam perekonomian Indonesia. $\mathrm{Al}$ Iqtishad: Jurnal Ilmu Ekonomi Syariah, 3(1).

Rusydiana, A. S., \& Firmansyah, I. (2018). Efficiency versus maqashid sharia index: An application on Indonesian Islamic Banks. Shirkah: Journal of Economics and Business, 2(2), 2503-4243.

Setiawan, I. (2019). Inovasi penyaluran dana zakat pada program pemberdayaan di lembaga amil zakat. Asy-Syari'ah, 21(1), 55-68.

Syofyan, A. (2017). Analisis kinerja bank syariah dengan metode indeks maqasid syariah di Indonesia. Al-Masraf: Jurnal Lembaga Keuangan dan Perbankan, 2(2), 145-158.

Triyuwono, I. S. (2001). Metafora zakat dan shari'ah enterprise theory sebagai konsep dasar dalam membentuk akuntansi syari'ah. Indonesian Journal of Accounting and Auditing, 5(2), 131-145.

Toriquddin, M. (2015). Pengelolaan zakat produktif di rumah zakat kota Malang perspektif maqashid al-syariah Ibnu 'Asyur. Ulul Albab: Jurnal Studi Islam, 16(1), 62-79
Ataina Hudayati

Universitas Islam Indonesia

ataina.hudayati@uii.ac.id

Achmad Tohirin

Universitas Islam Indonesia 